\title{
Human Resources (HR) as a Strategic Business Partner: Value Creation and Risk Reduction Capacity
}

\author{
Fotios V. Mitsakis \\ Dept. of Human Resource Management, University of Strathclyde \\ Glasgow G1 1XU, Scotland \\ E-mails: fotis.mitsakis@strath.ac.uk / fotisathens@hotmail.com
}

Doi:10.5296/ijhrs.v4i1.5285 URL: http://dx.doi.org/10.5296/ijhrs.v4i1.5285

\begin{abstract}
The competitive forces firms face today, and will continue to face in the future, demand organizational excellence through which HR departments could make a real contribution to the business through their value-added and risk reduction capacity, while been accepted as equal strategic business partners in organizations. The article discusses HR department's capability of being seen as an integrated value-driven business function, while it also demonstrates its risk reduction capacity, both critical outcomes of HR's strategic positioning within the business agenda.
\end{abstract}

Keywords: Human Resources (HR), Strategic Business Partner, Value Creation, Risk Reduction.

\section{HR as a Strategic Business Partner}

For strategic HR to emerge, it is essential for specific characteristics to exist, but also to be well integrated so to create an "internal fit". All are important in their own right, but they are also interrelated. If one or more is absent or weak, then this could significantly undermine the development of strategic HR, because the links with other characteristics would also be weakened (McCracken \& Wallace, 2000a, 2000b). Meeting the strategic criteria of the numerous strategic HR models, HR professionals would be able to move closer of being accepted as equal strategic business partners within their organizations. HR's credibility will also be enhanced by helping clients to meet their business and performance needs, and ultimately through the achievement of the organizational strategic business goals and objectives (Gilley et al., 2002). Developing strategic business partnerships is also absolutely critical to the success of strategically integrated HR programs. In order to be successful, HR executives need to develop collaborative client relationships as a way of enhancing their image and credibility. Furthermore, they have to become knowledgeable about the concept of demand and the various demand states of their clients. Creating a strategically integrated HR 
program and strategy will enhance the "good work" process provided by HR departments, without going largely unnoticed as before (Gilley et al., 2002).

\subsection{Traditional Approaches to Strategic HR - Need-Driven HR}

The strategic role of HR can be further examined through its traditional approaches of: (1) need-driven HR, (2) opportunities-driven HR, and (3) capability-driven HR. With a need-driven HR approach, its role, in relation to strategy, is to assess and address skill deficiencies within organizations (Mabey \& Salaman, 1995). A firm can pursue its strategy if its people live up to their roles and possess the appropriate competencies, which can alter through environmental changes or company's resources variation. When people fail to fulfil their roles, they face a skill performance gap. To be of strategic value, a "gap closing" HR approach must work with such skill deficiencies that are seriously keeping the organization from achieving its objectives (Luoma, 2000b). However, it is important to note that a strategic gap can exist anywhere within the workforce at any level. Therefore, adapting a HR approach of this kind calls for constant evaluation of those factors affecting the expected performance of an individual, a group, or the entire workforce. A change in these factors has to be translated into new competence profiles, and eventually the gap identified has to be closed by HR initiatives (Luoma, 2000b). There is no doubt that this approach is strategic in nature; strategic in the sense that unless the emerging needs are being taken care of, the implementation of strategy is compromised. When a company is forging ahead towards its objectives, and the critical parts of the organization face a lack of appropriate competence, HR is used for closing the performance skill gaps, while assisting the progress, and eventually helping the business strategy to happen (Luoma, 2000b). In that event, strategic HR alignment can be viewed both as an outcome (focus on HR investment decision making and evaluation) and as a process (interaction between the HR function and stakeholders), by paying attention on methods, structures and measures of the strategy's planning process (Anderson, 2009: 266), and by involving interactions between stakeholders, values and communication and understanding processes (Avison et al., 2004). A typical example comes from the findings of Lawler and Mohrman's (2003) study, clearly stressing that when HR is perceived as an equal strategic business partner, while being involved in the development and implementation of corporate strategy, resultantly the benefits are of multiple value for the organization. However, a "need-driven" HR approach is quite reactive in nature; it can be described as being opportunistic, since the activities carried out are not indispensable fixes for flaws in performance, but possibilities for an organization to perform even better than in the past (Luoma, 2000b).

\subsection{Opportunity-Driven HR}

Other concepts of strategic HR have their interest in the outer world of business development, and in the interventions and techniques that are employed as catalysts for mental growth in organizations, and which are frequently associated with organization leaders seeking to manage cultural change amongst their workforce (Mabey \& Salaman, 
1995). Through interventions derived from these leading guidelines of organizational behavior, the company acquires such abilities and patterns of behavior, making it more efficient today or providing a valuable source of competitiveness for the future. In today's turbulent business environment, organizations encounter a constant stream of developmental options available, and part of the job of their HR departments is to recognize those trims that can possibly result to value proposition for organizations, while enhancing their competitiveness (Luoma, 2000b). In this regard, Barney and Wright (1997) underlined HR's role (as strategic business partner) in providing competitive advantage to organizations, while quite similarly, Cascio's (2005) work demonstrated HR's ability of driving organizational success, simply by undertaking greater responsibility and accountability in any business functional area. The approach based on utilizing external development opportunities can be termed as the "opportunity-driven" HR approach. Instead of seeing HR as a cure to well-articulated development needs, companies adapting this approach emphasize the learning potential in their people. Usually, that kind of HR is used for providing employees with non-vocational skills such as systems thinking and business process analysis (Torraco \& Swanson, 1995).

\subsection{Capability-Driven HR}

Finally, strategic HR can also be used for delivering organizational capabilities, which can make a major contribution to the organization's performance. More precisely, during economic crises, following a more strategic approach can result to two major contributions. First, it provides organizations with operational capabilities to manage crises, and second, it allows them understand a basic objective of crisis management, which is to accumulate wisdom by learning together from an event to prevent, so being able to improve organizational responses to future crises events (Hillyard, 2000). In that event, Ulrich (1997: 10) stated that "Capabilities are the DNA of competitiveness. They are the things an organization always does better than its competitors do", while Ulrich et al., (2008: 22) further argued that organizational capabilities are the "collective abilities of an organization which are demonstrated in various ways by the organization's members, though not dependent on any one individual". Additionally, organizational capabilities represent behaviors which are not directly connected to tangible or intangible resources (Saint-Onge \& Wallace, 2003: 3; Teece et al., 1997), but they present in a certain organizational setting; hence, they should be emphasized as the primary object of strategy, and managerial attention should be focused on factors that support these capabilities (Luoma, 2000a; Stalk et al., 1992). In this regard, Ulrich and Smallwood (2004: 4) identified eleven organizational capabilities that can typically create and sustain a competitive advantage, and can be categorized as it follows: talent, speed, shared mind-set, accountability, collaboration, learning, leadership, customer connectivity, strategic unity, innovation, and efficiency, all of which can be seen as "the outcome of investments in staffing, training, compensation, communication, and other human resources areas" (p.5). Since, capabilities are about the way people act, most of the time, it is difficult for competitors to copy them because they are based on knowledge, skills, and processes developed over time into workable combinations within the context of a 
particular organizational setting. For the same reason they are also difficult to suddenly change. However, by the time they create value for the customer, they can be viewed as source of lasting competitive advantage (Long \& Vickers-Koch, 1995). In that event, Ulrich and Smallwood (2004) argued that an organization's competitive advantage is typically derived by outweighing at least three of the eleven capabilities. Strategic HR initiatives can deliver these organizational capabilities, but as a distinction to the traditional approaches, this calls for the alignment of other HR practices and modification of organizational structure as well; eventually, that makes the "capability-driven" HR proactive in nature (Luoma, 2000a).

The implementation stage of a HR strategy is highly influenced by the organization, the HR department, the organizational policies related to HR participation, the HR philosophy, internal branding of HR, flexibility of HR systems, competency of HR staff, availability of resources, support of line managers (LMs), level of HR knowledge of LMs, level of HR training to non-HR executives, employment laws and regulations, and labor market conditions (Krishnan \& Singh, 2004). Obviously, the necessity of a more strategic HR approach is pivotal to new business reality. HR professionals need to reconsider their department's importance in the decision making process and strategy formulation as well. That eventually will increase their interventions' value proposition and risk reduction capacity respectively. In the context of the economic crisis, SHRD can play a critical role in ensuring that past learning does not hinder new learning and that insights learned from the past are used to prevent future impacts of the recession (Wang et al., 2009).

\section{HR as an Integrated Value-Driven Business Function}

The competitive forces firms face today, and will continue to face in the future, demand organizational excellence through which HR departments could make a real contribution to the business through their value-added and risk reduction capacity. Unfortunately, many firms still follow a "transactional" and administrative role for their HR practices, and eventually their HR departments are viewed as necessary, but not of great value. Strategic HR differs significantly from the traditional one. The main responsibility for managing human resources in a traditional way rests with specialists in a division (large companies) or team. In the strategic approach, the main responsibility for people management rests with any individual who is in direct contact with them or a LM; moreover, strategic HR leads, inspires and understands others, while its traditional approach just responds to needs (Ivancevich, 2007). Quite similarly, as suggested by Gibb (2008), and from a strategic HR value proposition perspective, organizations are always trying to generate valued outcomes, which differentiate among them based on the strategic focus they follow (pp.309-310).

Due to radical changes occurred the last decade, HR concentrates on getting things done through people, simply by designing an entirely new role and agenda that result in enriching the organization's value to multiple stakeholders (Ulrich, 1998). This HR shift highly matters to employees, who realize that their skills and competencies to perform their jobs, and their commitment or ability to focus their attention, derive in part from how HR practices affect them. Customers, who desire to maintain long term and increasingly complex relationships with a company, recognize that an organization's HR practices can assure a steady flow of 
products and services (Ulrich \& Brockbank, 2000a, 2005b), while investors who realize that intangibles determine a large source of a company's wealth (brand image \& reputation), increasingly look at HR as a source of a firm's market value (Ulrich \& Brockbank, 2005b). HR will be able to help organizations meet competitive challenges such as globalization, profitability through growth, technology, intellectual capital and nonstop change, only by developing a strategic architecture that aligns with and supports company's overall vision and mission (Sparrow, 2008) and can be reached and evidenced through the following three ways of value creation, value improvement and leverage, and value protection and preservation (Sparrow et al, 2008).

\subsection{HR's Value Proposition through the 4 phases of organization's strategy formulation}

HR activities (resourcing, training \& development, rewards, communications and general administration) can add value every time they involved throughout all phases of the organization's strategy formulation (Towers, 2006). Early involvement of HR in the strategic decision making process is important as it enables its professionals to influence board decisions (phase A). Moreover, HR initiatives can also be used as a means of implementing decisions that have been made (faze B). Furthermore, HR professionals operate at the later stages in the implementation stage through their functions such as in communication and recruitment (phase C) and finally, their value proposition can derive through noticing things that are not going as planned and implementing HR techniques to rectify them (phase D)-(Brewster \& Harris, 1999). This also can be shown by linking the perspective of the HR Architecture with the concept of the Strategy Map (Figure 1) for a successful HR value proposition (Figure 2).



Figure 1: HR Architecture and Strategy Map (Brewster \& Harris, 1999).

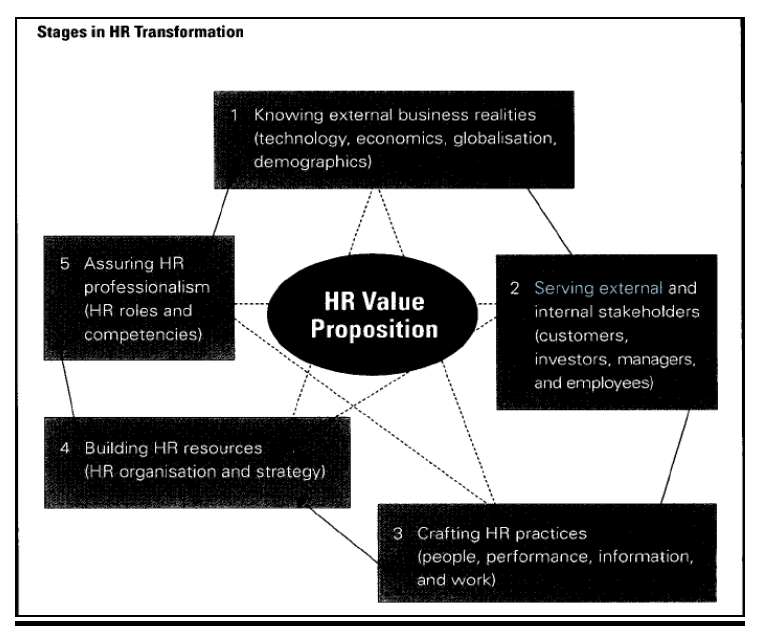

Figure 2: The HR Value Proposition (Brewster \& Harris, 1999).

Defining the focus and value of HR within the business is very critical, following a strategic people-oriented and process-centered HR approach. The work of Hiltrop and Despres (1995) illustrates the strategic audit of HR among all the subsidiaries of United Technologies Corporation. They argued that one way of finding out whether HR follows a business driven approach in a particular organization is to investigate what other managers 
think of it. With their questionnaire and the responses given, they highlighted that HR requires a reasonable access to top management thinking, to LMs, and to formal planning documents, while concurrently being involved at the beginning of each new strategy formulation, so that a proactive role can be played. Finally, they concluded that the central strategic role is about how HR's voice is expressed and heard during corporate strategy's formulation, by highlighting its business driven role through aligning its policies and actions with business strategies (Hiltrop \& Despres, 1995). The ability to align both management systems with the quality of strategy execution tends to increase the level of the desirable employee's behavior standards and their strategic focus, which eventually creates an "invisible asset" that tends to be idiosyncratic to the individual firm and not easily imitated by competitors (Becker et al, 2001).

Obviously, the HR department is just one of the several business functions, whose value-added capacity derives through its involvement at the strategic level of decision-making process, by simultaneously ensuring a continuous and consistent inflow of resources (Yeung \& Berman, 1997). In this regard, Spencer (1995) identified that HR can deliver value to an organization in three major areas. HR's main value is situated in the strategic domain (compensation policies, executive development and succession planning), secondly within the HR practices (recruitment, training, counselling, performance management etc.) and finally, through its administration services (record keeping, compliance etc.) which is the domain offering the minimum benefit. Huselid's (1995) study also outlined a strong relationship between high performance work practices (HPWP) and corporate and financial performance. The author also concluded that effective HPWP have a significant impact upon labor turnover and productivity, and in short and long term financial performance, respectively. That is why, and in accordance to the results of Human Capital Index Survey from Watson Wyatt (2002), a HR consultant asserted that "Great people management equals great shareholder value: European companies with the best human capital management managed to deliver around twice as much shareholder value as their average competitors, while companies with weak people management practices produced negative returns on equity". In a similar vein, Pfeffer (1994) argued that the "best practice" approach advocates that a standard set of HR practices of high performance work systems (HPWS) can lead to superior organizational performance. He further identified a list of seven HR practices of successful organizations, such as: (a) Employment security, (b) Selective hiring of new personnel, (c) Self-managed teams and decentralization of decision making as the basic principles of organizational design, (d) High compensation contingent on organizational performance, (e) Extensive training, (f) equal employment opportunities, and (g) broad knowledge sharing and clear communication. However, the implementation of HPWP varies systematically, according to the demand characteristics of the customer segment served, where such practices are more likely to be utilized in higher value-added markets (Batt, 2000). Birdthistle (2006) and Lin and Jacobs (2008) also stressed the significant role of such practices and their relation to enhanced business performance, success and longevity, while others accentuated their importance as tools of creating sustainable competitive advantage (Jones et al., 2013; Tharenou et al., 2007; Aragon-Sanchez et al., 2003; Huang, 2011). In that event, Hallier and Butts (1999) argued that organizational performance 
can be downsized in organizations where HR initiatives are discarded.

HR can create sustainable competitive advantage that is why many HR managers frequently refer to "Management of the Employee" as an area where HR can demonstrate its value-driven capability (Buyens \& De Vos, 2001). People can limit or enhance organizational strengths and weaknesses; hence, focusing on Human Capital Effectiveness can help them driving forward their goals through motivated and multi-skilled employees, employment stability, shared mind-set, and through a strong link between personal and corporate goals. In this regard, Holton and Yamkovenko (2008) stated that human capital's advantage emanates through the process of advancing both informal and formal knowledge within all organizational levels. Furthermore, the link between people management practices and organizational performance can be evidenced through the following three approaches: (a) Best practice, (b) Strategic contingencies, and (c) Configuration of practices (Sparrow et al., 2005).

\subsection{Value Proposition through Effective Recruitment and Selection}

The unique way in which HR departments add value to the organization is the effective recruitment and selection of those employees demonstrating the appropriate competencies so to better fit within the organizational context (culture, climate etc.) in order to be able to build organizational capability for leadership (Wright \& Snell, 2005). Holbeche (2009) argued that recruitment is an area where there is a high amount of potential risk, as if it is done quickly and without care, then the wrong sort of employees can enter the organization, and the effect of this upon organizations can be very disastrous. Contrariwise, the benefits of hiring the appropriate people for any job vacancies should result to low turnover, low absenteeism, increased individual and organizational efficiency, and the enforcement of tacit knowledge within the organization.

\subsection{Value Proposition through Employees' Development}

Furthermore, employees' further development on acquiring intercultural skills is considered important, as modern workplaces are increasingly becoming multicultural and globalized (Stevens, 2013). Many HR managers associate these skills with significant business benefits, such as effective and efficient team administration and working, the development of new or existing relationships with clients, creativity, improved communication, and lower organizational conflicts (Stevens, 2013). The Resource-based view approach indicates HRD function as a very important business operation focusing on building and maintaining organizational competitive advantage through its continuous human capital developmental activities, by matching new knowledge with the environment's opportunities and challenges (Thompson \& Strickland, 2002).

\subsection{Value Proposition through Reduced Turnover}

Peterson (2005) also recognized that HR departments demonstrate value through helping 
reduce labor turnover, but also can be seen to have demonstrated risk reduction. Furthermore, according to Attersley (2005) and Huselid (1995) studies, absenteeism has become a widespread problem, as $75 \%$ of a typical firm's annual operating budgets are spent on human capital costs and therefore it can cost companies millions of Euros. HR departments can demonstrate their added value, simply by managing to control or to reduce the above percentage of human's capital cost. Consequently, HR can increase profits through better supporting of these processes that generate revenues.

\subsection{Value Proposition through Employees' Motivation}

HR can also help employees in three vital areas; ability, motivation and opportunity. HR departments provide opportunities for all employees to receive relevant training; they provide motivational rewards and allow their employees to contribute to decision making (Appelbaum et al., 2000). The HR Manager, like all managers, is expected to play a critical role in improving the skills of his/her workforce, and eventually firm's profitability. In that event, appraisal systems, if they carried effectively, they could have an excellent impact upon motivation. Through successful career planning, HR departments can help their employees to unleash their full potential and to become organizational leaders. Many studies have shown that effective people management was linked to a high increase $(90 \%)$ in shareholder value (Xirogiannis et al., 2008; Ulrich \& Smallwood, 2004; Amit \& Belcourt, 1999; Becker et al., 1997; Buhner, 1997). Furthermore, HR professionals who design reward systems, such as "payment by results" (PBR) or "performance-related pay" (PRP), they should encourage their employees being more productive so to enable organizations being more flexible. In this regard, investments in HR initiatives would enable employees to further advance their skills, whilst appraisals or PRP would encourage them to meet targets, acting as a motivator which eventually adds value to the organization. Especially in mergers, HR strategies are used to reassure employees and to provide job security. Providing a secure working environment, coupled with effective performance management, can result to a high-valued workforce (Watson Wyatt, 2002; Parmenter, 2002).

To sum up, we can easily identify a very clear positive relationship between what we call a high performance HR system and various measures of firm's performance. The work of Huselid (1995), Yeung and Berman (1997) and Appelbaum et al. (2000) showed a positive correlation between cumulative human resources functions and business performance. We just have to emphasize on employees' performance in every aspect of the system, trying to be consistent and fully aligned with the strategy of the organization. Depending on the focus of business' strategy (innovation, cost reduction etc.) and the type of employee role behaviors, there is an appropriate set of HR practices. For creating value-driven HR within organizations, managers need to recognize it as an equal strategic business partner with great impact on stakeholders' interests. HR professionals have to develop more powerful HR agendas, designed for delivering HR value, and then to develop their professionals, making them capable of delivering these agendas (Ulrich \& Brockbank, 2005a, 2005b). To that end, HR executives need to be aware of the confluence of economic, social, and technological forces 
that drive industry competition, so to be able to create value through their HR deliverables (Wright \& Snell, 2005). Further down, HR policies and practices should aim at effectively managing and utilizing people; implementing performance appraisals and reward employees according to their performance; provide developmental opportunities for all organizational members so to enhance their innovation, creativity and flexibility, and eventually to increase business competitiveness; applying changes to the extent they lead to improved staffing, training and communication channels for the common good of the company and its employees. A real contribution to performance, in its multidimensional meaning, will only happen once we approach HR from a more holistic and balanced perspective, including part of the organizational climate and culture, aimed at bringing about the alignment between individual values, corporate values and societal values (Paauwe \& Boselie, 2005). There is thus an important role for an astutely formed HR strategy, for a blend of people management practices and investments which will help the organization to develop innovative and agile behavior, while not neglecting the stable harvesting of its existing operations (Boxall, 2003). In this regard, organizations have to continuously train and develop their employees, by building their skills, knowledge and capabilities for making them capable of reaching competitive advantage through a well-trained, qualified and competitive workforce. For the economy as a whole, employees' higher skills, competencies, and capabilities can lead to more prosperous economies and more profitable companies as well (Radic et al., 2012: 561). Accordingly, MacDuffie (1995: 200) stated that "innovative human resource practices are likely to contribute to improved economic performance only when three conditions are met: when employees possess knowledge and skills that managers lack; when employees are motivated to apply these skills and knowledge through discretionary effort; and when the firm's business or production strategy can only be achieved when employees contribute such discretionary effort". This will be a unique blending for each organization, which is difficult to grasp by outsiders - competitors and thus contributes to sustained competitive advantage (Paauwe \& Boseile, 2005).

\section{HR and its Risk Reduction Capacity}

The key part is than an organization's workforce could play a major role to its effectiveness, since everything is around people. Although employees can be viewed as a source of sustainable competitive advantage for businesses, human capital costs often make up the largest part of company investments. Whilst HR involves the management and development of a key source of sustainable competitive advantage, HR departments also act as a means of reducing risk for organizations (Towers, 2006). According to Flouris and Yilmaz (2010) "risk management to human factor is the process of identifying and assessing human factor based risk and then developing strategies to SHRM", through a holistic and proactive consideration of human capabilities and limitations. HR can play two roles in risk management, firstly by identifying people as a source of risk (e.g. shortage of employees, underperforming and inefficient employees, employees' resistance to change or to undertake additional responsibilities, employee turnover, absenteeism etc.), or by seeing them as a means of handling risk (e.g. employees innovation/creativity to provide solutions, employees' 
engagement and commitment, change facilitators, word of mouth etc.)-(Erven, 2012). Obviously, employees' behavior has important implications to business performance. Various HR practices can affect individual performance either through influencing employees' skills and motivation or through establishing organizational structures which allow employees to improve how their jobs are performed. Therefore, if superior HR practices increase employees' discretionary effort, it will directly affect intermediate outcomes, such as turnover and productivity, which in turn would enhance corporate financial performance (Huselid, 1995).

\subsection{Risk Reduction through Effective Recruitment and Selection, Training and Development $(T \& D)$, and Communication}

HR can reduce risk within organizations through its activities in resourcing, T\&D, reward systems and communication with the workforce. Holbeche (2009) stated that HR professionals need to apply risk management techniques to their tasks. He further argued that recruitment is an area where there is a high amount of potential risk as if it is done quickly and without care, the wrong sort of employees can enter an organization. That would be proved disastrous for organizations. Moreover, if recruitment is not done carefully, it can also result in high labor turnover and low productivity. McEvoy and Cascio's (1985) work demonstrated that job enrichment interventions and realistic job previews were moderately effective in reducing turnover, which eventually results to an important influence on organizational productivity. Finally, according to Peterson (2005) and Chandler and McEvoy (2000), training, goal setting and "sociotechnical systems design" can also have significant positive effects on labor turnover, productivity, and cost minimization. There is much evidence within the literature, showing the positive relationship between training and lower labor turnover and high employees' retention rate (Ghebregiorgis \& Karsten, 2007; Gelade \& Ivery, 2003; Paul \& Anantharaman, 2003; Vandenberg et al., 1999). Employees' further development can result to increased levels of satisfaction, commitment and sense of belonging; eventually, employees tend to stay with the organization and to contribute to organization's competitiveness (Acton \& Golden, 2003). Hence, besides the added value for organizations, risks can also be diminished. An increasing prevalent issue is also employees' absenteeism in organizations (Towers, 2006). HR has the opportunity to demonstrate its value by effectively managing absenteeism and reducing risks associated with employees' mismanagement of organizational resources. A study conducted by Katz et al (1985) outlined that a highly effective industrial relations system (fewer grievances, disciplinary actions and lower absenteeism) tend to increase product quality and to direct labor efficiency. Quite similarly, an alternative way to manage risk is by reducing the magnitude of loss incurred when an event happens (e.g. a key employee's absence stops an entire production process). In such events, HR can facilitate cross training of others to cover that position and reduce the adverse impact of a missed day (Ruona \& Armstrong, 2002).

Further down, inefficient and unproductive employees represent a liability and pose great risk to organizational competitiveness. Through strategic HR initiatives, employees can be encouraged to be much more efficient and productive. McElroy (2001) argued that more 
training and learning opportunities can increase employees' perception of being valued by their organization, while helping them to attract and retain the most talented one within it. Furthermore, investing in employees' development will result to cost savings through reduced absenteeism and turnover (Maurer \& Lippstreu, 2008; Foong-Ming, 2008); better recruitment processes and training activities (Sieben, 2007); enhanced organizational learning culture (Joo, 2010); and increased levels of employees' commitment and engagement since there is convergence among employees' and organization's goals and objectives (Vancouver \& Kendalll, 2006). More precisely, T\&D would enable employees to expand their skills, whilst appraisals or performance-related pay schemes would also encourage them to reach targets, and eventually resulting in higher commitment and engagement rates. In that event, firms putting up their workforce's commitment are less likely to use temporary employees and more likely to invest in innovative work practices such as skills training and incentive compensation (Erven, 2012). A tangible focus on employee commitment can be expected to help produce a stable core of employees, thus increasing the probability that a firm will reap the benefits associated with investments in training (Osterman, 1994).

HR can further eliminate risk through ensuring a clear and effective communication process between top management and the workforce. The fact that HR departments help in times of organizational change to enhance communication channels suggests that without them, organizations would seriously lack basic organizational capabilities which threaten the viability of implementing change (Towers, 2006).

To sum up, HR activities can lead to four important suggestions for risk management. First, they can assure human resources' harmonization. As risk management decisions are carried out by people, firms should have the "right" people in the right place, while trying to keep them well trained, highly motivated and rewarded them accordingly. Second, HR "afflictions" (e.g. employees' divorces, illness, work accidents, deaths, unsustainable lifestyle, financial difficulties etc.) can impede carefully made risk management decisions. Effective risk management should be able to confront these HR calamities; therefore, strategic HR planning needs to be seen as an essential business feature of the risk management decision making process, since management's succession is highly dependable to risk levels (Erven, 2012). In this regard, HR professionals have to carefully review HR, legal, financial and other considerations, all of which can directly affect management's succession and thus risk management decisions.

\section{Conclusion}

Obviously, a HR system encompasses many different functions, all of which can deliver value in different ways for organizations. Real progress can only be achieved by looking at the broader picture of developments in the field of strategic management, the speed of change within firms and what this implies for managing people and stakeholders. In that event, all HR activities (job analysis, job descriptions, selection, T\&D, training evaluation, performance appraisal, rewards etc.) must be considered and should be integrated to risk 
management strategies as well, since HR failures can cause the best planned business strategies to fail (Erven, 2012). For all that to happen, HR, and its professionals, need to be accounted as equal business partners, by strategically integrating their strategies, policies and plans to the overall business strategy.

\section{References}

Acton, T. and Golden, W. (2003). Training the knowledge worker: A descriptive study of training practices in Irish software companies. Journal of European Industrial Training, Vol.27, No.4, pp.137-146.

Amit, R. and Belcourt, M. (1999). Human resources management processes: a value-creating source of competitive advantage. European Management Journal, Vol.17, Issue 2, pp.174-181.

Anderson, V. (2009). Desperately seeking alignment: reflections of senior line managers and HRD executives. Human Resource Development International, Vol.12, Issue 3, pp.263-277.

Appelbaum, E., Bailey, K., Berg, P. and Kalleberg, A.L. (2000). Manufacturing Advantage: Why High Performance Work Systems Pay Off. Ithaca, Cornell University Press.

Aragon-Sanchez, A., Barba-Aragon I. and Sanz-Valle, R. (2003). Effect of training on business results. The International Journal of Human Resource Management, Vol.14, Issue 6, pp.956-980.

Attersley, J. (2005). Absence makes the bottom line wander. Canadian Human Resources Reporter, The National Journal of Human Resource Management, Vol.18 (19): pp.1-2.

Avison, D., Jones, J., Powell, P. and Wilson, D. (2004). Using and validating the strategic alignment model. Journal of Strategic Information Systems, Vol.3, Issue 3, pp.223-246.

Barney, J.B. and Wright, P.M. (1997). On becoming a strategic partner: the role of human resources in gaining competitive advantage. CAHRS Working Paper, No.97-09, Ithaca, NY: Cornell University, Center for Advanced Human Resource Studies, Assessed through: http://digitalcommons.ilr.cornell.edu/cahrswp/150

Batt, R. (2000). Strategic segmentation in front-line services: Matching customers, employees and human resource systems. International Journal of Human Resource Management, Vol.11, No.3, pp.540-561.

Becker, E.B., Huselid, A.M. and Ulrich, D. (2001). The HR Scorecard; Linking People, Strategy, and Performance. Harvard Business School Press, Boston, pp.3-7.

Becker, E.B., Huselid, A.M., Pickus, S.P. and Spratt F.M. (1997). HR as a Source of shareholder Value: Research and Recommendations. Human Resource Management, Vol.36, No.1, pp.39-47.

Birdthistle, N. (2006). Training and learning strategies of family businesses: an Irish case. Journal of European Industrial Training, Vol.30, Issue 7, pp.550-568. 
Boxall, P. (2003). HR strategy and competitive advantage in the service sector. Human Resource Management Journal, Vol.13, No.3, pp.5-20.

Brewster, C. and Harris, H. (1999). International HRM: Contemporary Issues in Europe. Routledge.

Buhner, R. (1997). Increasing Shareholder Value through Human Asset Management. Long Range Planning, Vol.30, No.5, pp.710-717.

Buyens, D. and DeVos, A. (2001). Adding Value through Integration and Involvement: A Qualitative Study about Management's Perception of the Added Value of the HR Function. Vlerick Leuven Gent Management School, HRM Journal, 2001, Vol.11, Issue 3, pp.70-89.

Cascio, F.W. (2005). From Business Partner to Driving Business Success: The Next Step in the Evolution of HR Management. Human Resource Management. Vol.44, Issue 2, pp.159-163.

Chandler, G. and McEvoy, G. (2000). Human resource management, TQM and firm performance in small and medium-sized enterprises. Entrepreneurial Theory and Practice, Vol.25, Issue 1, pp.43-58.

Erven, L.B. (2012). The role of human resource management in risk management. Ohio State University Agricultural, Environmental and Development Economics, http://www.extension.org/pages/15506/the-role-of-human-resource-management-in-risk-man agement

Flouris, T. and Yilmaz, K.A. (2010). The Risk Management Framework to Strategic Human Resource Management. International Research Journal of Finance and Economics, Issue 36, Euro Journals Publishing, Inc., 2010, pp.1-5.

Foong-Ming, T. (2008). Linking Career development practices to turnover intention: The mediator of perceived organizational support. Journal of Business and Public Affairs, Vol.2, Issue 1, pp.1-20.

Gelade, G.A. and Ivery, M. (2003). The impact of human resource management and work climate on organizational performance. Personnel Psychology, Vol.56, Issue 2, pp.383-404.

Ghebregiorgis, F. and Karsten, L. (2007). Human resource management and performance in a developing country. International Journal of Human Resource Management, Vol.18, Issue 2, pp.321-332.

Gibb, S. (2008). Human Resource Development: Process, Practices and Perspectives. $2^{\text {nd }}$ Edition, Palgrave Macmillan, p.11, p.172, pp.181-182, pp.308-310, pp.324-326.

Gilley, W.J., Eggland, A.S. and Gilley, M.A. (2002). Principles of Human Resource Development. $2^{\text {nd }}$ edition, Basic Books (Perseus Book Group) Publishing.

Hallier, J. and Butts, S. (1999). Employers' discovery of training: self-development, employability and the rhetoric of partnership. Employee Relations, Vol.21, Issue 1, pp.80-95. 
Hillyard, M.T. (2000). Public crisis management, how and why organizations work together to solve society's most threatening problems. San Jose, CA: Writers Press Club, p. 9.

Hiltrop, J-M. and Despres, C., (1995). Benchmarking HR Practices: Approaches, rationales, and prescriptions for action. In Hussey D.E., (1995). Re-thinking Strategic Management. Chichester, John Wiley, p.201.

Holbeche, L. (2009). Aligning human resources and business strategy. $2^{\text {nd }}$ Edition, Oxford, UK: Butterworth Heinemann, Elsevier Ltd.

Holton, E.F. and Yamkovenko, B. (2008). Strategic intellectual capital development: A defining paradigm for HRD?, Human Resource Development Review, Vol.7, No.3, pp. 270-291.

Huang, T. (2001). The relation of training practices and organizational performance in small and medium size enterprises. Education and Training, Vol.43, No.8-9, pp.437-444.

Huselid, M.A. (1995). The impact of Human Resource Management Practices on Turnover, Productivity, and Corporate Financial Performance. Academy of Management Journal, Vol.38, No.3, pp.635-672.

Ivancevich, J.M. (2007). Human Resource Management. New York: New York: McGraw-Hill / Irwin.

Jones, P., Beynon, J.M., Pickernell, D. and Packham, G. (2013). Evaluating the impact of different training methods on SME business performance. Environment and Planning $C$ : Government and Policy, Vol.31, Issue 1, pp.56-81.

Joo, B.K.B. (2010). Organizational commitment for knowledge workers: The roles of perceived organizational learning culture, leader-member exchange quality, and turnover intention. Human Resource Development Quarterly, Vol.21, Issue 1, pp.69-85.

Katz, H.C., Kochan, T.A. and Weber, M.R., (1985). Assessing the effects of industrial relations systems and efforts to improve the quality of working life on organizational effectiveness. Academy of Management Journal, Vol.28, issue 3, pp.509-526.

Krishnan, S. and Singh, M. (2004). Strategic Human Resource Management: Three-Stage Process and Influencing Organizational Factors. Personnel and Industrial Relations Area D-18, Indian Institute of Management, pp.4-26.

Lawler, E.E. and Mohrman, A.S. (2003). HR as a Strategic Partner: What Does It Take to Make It Happen?, Center for Effective Organizations, Marshall School of Business, University of Southern California, p.1-30, Available at: http://dwashingtonllc.com/pdf/hr_strategic_partner.pdf

Long, C. and Vickers-Koch, M. (1995). Using core capabilities to create competitive advantage. Organizational Dynamics, Vol.24 (1), pp.7-22.

Luoma, M. (2000a). Developing people for business success: Capability-driven HRD in practice. Management Decision, Vol.38, No.3, pp.145-153. 
Luoma, M. (2000b). Investigating the link between strategy and HRD. Personnel Review, Vol.29, Issue 6, pp.769-790.

Mabey, C. and Salaman, G. (1995). Strategic Human Resource Management. Blackwell, Oxford, p.143.

MacDuffie, J.P. (1995). Human resource bundles and manufacturing performance: organizational logic and flexible production systems in the world auto industry. Industrial and Labor Relations Review, Vol.48, No.2, pp.197-221.

Maurer, T.J. and Lippstreu, M. (2008). Who will be committed to an organization that provides support for employee development?, Journal of Management Development, Vol.27, Issue 3, pp.328-347.

McCracken, M. and Wallace, M. (2000a). Towards a Redefinition of Strategic HRD. Journal of European Industrial Training, Vol.24, Issue 5, pp.281-290.

McCracken, M. and Wallace, M. (2000b). Exploring Strategic Maturity in HRD-Rhetoric, Aspiration or Reality?, Journal of European Industrial Training, Vol.24, Issue 8, pp.425-467.

McElroy, J.C. (2001). Managing workplace commitment by putting people first. Human Resource Management Review, Vol.11, Issue 3, pp.327-335.

McEvoy, G.M. and Cascio, W.F. (1985). Strategies for reducing employee turnover: A meta-analysis. Journal of Applied Psychology, Vol.70, Issue 2, pp.342-353.

Osterman, P. (1994). How common is workplace transformation and who adopts it? Industrial and Labor Relations Review, Vol.47, Issue 2, pp.173-188.

Paauwe, J. and Boselie, P. (2005). HRM and performance: What's next?, Human Resource Management Journal, Vol.15, Issue 4, pp.68-83.

Parmenter, D. (2002). How HR adds Value. New Zealand Management, Vol.49, Issue 10, p.36.

Paul, A. and Anantharaman, R. (2003). Impact of people management practices on organizational performance: Analysis of a causal model. International Journal of Human Resource Management, Vol.14, Issue 7, pp.1246-1266.

Peterson, C. (2005). Employee Retention: The Secrets behind Wal-Mart's Successful Hiring Policies. Human Resource Management, Vol.44, Issue 1, pp.85-88.

Pfeffer, J. (1994). Why do smart organizations occasionally do dumb things?, Organizational Dynamics, Vol.25 (1), pp.33-44.

Radic, V., Milosevic, D. and Sljivic, S. (2012). Understanding Organizations - Impact Managerial Work and Learning on Small Business Success. The First International Conference: "Employment, Education, and Entrepreneurship", 12-14 December 2012, Vol.3, Belgrade, Serbia, pp.547-564. 
Ruona, R.B. and Armstrong, D. (2002). Personnel Decision International. Consultants, Organizational Solutions Group, Atlanta, Georgia and Massachusetts.

Saint-Onge, H. and Wallace, D. (2003). Leveraging communities of practice for strategic advantage. Butterworth-Heinemann, Amsterdam, Netherlands.

Sieben, I. (2007). Does training trigger turnover - or not? The Impact of formal training on graduates' job search behaviour. Work, Employment and Society, Vol.21, No.3, pp.397-416.

Sparrow, P., Hesketh, A., Hird, M., Marsh, C. and Balain, S. (2008). Reversing the Arrow: Using Business Model Change to tie HR into Strategy. Centre for Performance-Led HR, July 2008, Lancaster University Management School, pp.11-13.

Spencer, L.M. (1995). Re-engineering Human Resources. New York: Wiley.

Stalk, G., Evans, P. and Shulman, L.E. (1992). Competing on capabilities: the new rules of corporate strategy. Harvard Business Review, March-April, pp.57-69.

Stevens, M. (2013). The Importance of intercultural skills: Does your organization value them more than professional qualifications?, Internet article on People Management, 7 http://www.peoplemanagement.co.uk/pm/articles/2013/03/the-importance-of-intercultural-ski

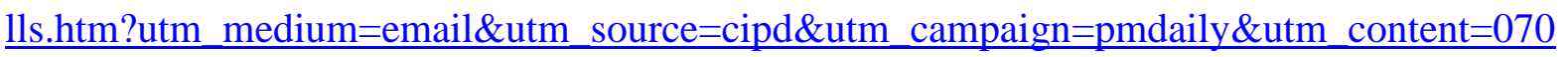
313_news_1

Teece, D.J., Pisano, G. and Shuen, A. (1997). Dynamic capabilities and strategic Management. Strategic Management Journal, Vol.18, No.7, pp.509-533.

Tharenou, P., Saks, A. and Moore, C. (2007). A review and critique of research on training and organizational-level outcomes. Human Resource Management Review, Vol.17, Issue 3, pp.251-273.

Thompson, A. and Strickland, A. (2002). Strategic Management: Concepts and Cases. $13^{\text {th }}$ Edition, London: McGraw-Hill / lrwin, Boston, Mass.

Torraco, R.J. and Swanson, R.A. (1995). The strategic roles of human resource development. Human Resource Planning, Vol. 18 No. 4, pp.10-21.

Towers, D. (2006). HR is far too obsessed with adding value. Would it not be better for HR Departments and HR Professionals to Concentrate upon the Risk Reduction Aspect of their Policies and Functions?, Human Resource Management, BCom International Commerce 2005/2006, The University of Birmingham.

Ulrich, D. (1997). Human Resource Champions: The Next Agenda for Adding Value and Delivering Results. Boston, Mass: Harvard Business School Press, 1997, p.10, p.160, p.236.

Ulrich, D. (1998). A new mandate for human resources. Harvard Business Review, Vol.76, Issue 1, pp.123-134.

Ulrich, D. and Brockbank, W. (2005a). The HR Value Proposition. Harvard Business School Press, Boston, Massachusetts, pp.45-94, pp.199-219. 


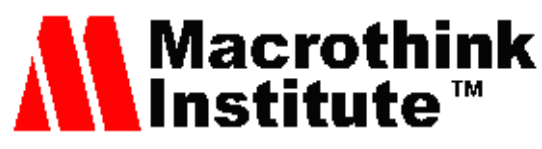

Ulrich, D. and Brockbank, W. (2005b). How HR adds Value. Human Resources Magazine, August 2005, Vol.10, Issue 3, pp.2-4.

Ulrich, D. and Smallwood, N. (2004). Capitalizing on capabilities. Harvard Business Review, Vol.82, Issue 6, pp.1-9.

Ulrich, D., Brockbank, W., Johnson, D., Sandholtz, K. and Younger, J. (2008). HR competencies: Mastery at the intersection of people and business. Alexandria, VA: Society for Human Resource Management.

Vancouver, J.B. and Kendall, L.N. (2006). When self-efficacy negatively relates to motivation and performance in a learning context. Journal of Applied Psychology, Vol.91, pp.1146-1153.

Wang, J., Hutchins, M.H. and Garavan, N.T. (2009). Exploring the Strategic Role of Human Resource Development in Organizational Crisis Management. Human Resource Development Review, Vol.8, No. 1, pp.22-53.

Watson Wyatt Company, (2002). Human Capital Index European Survey. Washington DC: The Wyatt Company, Available at: http://www.repec.org/sce2005/up.3657.1107167993.pdf

Wright, M.P. and Snell, A.S. (2005). Partner or Guardian; HR's Challenge in Balancing Value and Values. Human Resource Management, Vol.44, No.2, pp.177-182.

Xirogiannis, G., Chytas, P., Glykas, M. and Valiris G. (2008). Intelligent impact assessment of HRM to the shareholder value. Expert Systems with Applications, Vol.35, Issue 4, pp.2017-2031.

Yeung, A. and Berman, B. (1997). Adding Value through Human Resources: Reorienting Human Resource Measurement to Drive Business Performance. Human Resource Management, Vol.36, No.3, pp.321-335. 